\title{
Through the Looking Glass: Turkey in Europe
}

\author{
MELTEM MÜFTÜLER-BAC
}

This article discusses Turkey's role in Europe as a question of identity. As Europe reinvents itself along ethnic, cultural, and to a certain extent, racial lines, European perceptions of the "Turk" constitute serious obstacles to Turkey's integration into Europe. Turkey's hopes for full membership in the EU are far from being materialized because of questions regarding Turkey's Europeanness.

On March 4, 1997, at a meeting of the European People's Party - an alliance of European Christian Democratic Parties - in Brussels, the representatives of the Christian Democratic Party from six countries lead by Helmut Kohl declared that " the European Union [EU] is a civilization project and within this civilization project, Turkey has no place."' This declaration reflects the attitude in certain European quarters towards Turkey's eligibility for accession to the EU. This article proposes that the main obstacle to Turkey's membership in the EU is not the reasons that European officials formally cite - problems related to democracy, economics, and human rights - but rather, perceptions of Turkey as alien. This article emphasizes Turkish identity as the critical element in Turkey's exclusion from the EỨ, th̉ough such a tôcus does not, however, detract from the importance of other factors.

In its December 1997 summit in Luxembourg, the European Council decided to open accession negotiations with 11 applicant countries by dividing them into two waves. The first wave comprised Cyprus, the Czech Republic, Estonia, Hungary, Poland and Slovenia, ${ }^{2}$ and the second wave consisted of Bulgaria, Latvia, Lithuania, Romania and Slovakia. Accession Partnerships were concluded with each of these countries in 1998 as key parts of the pre-accession strategy. The decision not to include Turkey among the candidates for accession calls into question the EU's objectivity in evaluating candidate countries, since Turkey has a more developed market economy than most of these countries and its political problems are no worse than those of many of the other applicants. ${ }^{3}$

Turkey - the applicant country with the longest association with the European Community/EU - was left out in the cold. A June 1998 
European proposal to prepare Turkey for accession failed to satisfy Ankara, principally because it expanded areas in which Turkey had to improve without the promise of an accession partnership. Turkish perceptions of the EU as a closed cultural and religious club were strengthened by the European Council's failure to produce a credible explanation for not opening negotiations, given that negotiations do not guarantee accession. The Luxembourg decisions were amended to a certain extent by the European Council's decision in its Helsinki summit of December 1999 to elevate Turkey's position from an applicant to a candidate country. Nevertheless, the Council did not include Turkey among the second wave countries with which accession negotiations will begin in early 2000 . In fact, Turkey now is the only candidate country that is not going to start negotiations with the EU.

The future of Turkey within the EU is more complicated than that of other candidate countries because of questions regarding Turkey's identity. A Muslim country sitting on Europe's outer banks, it does not fit into Christian Europe or the Islamic Middle East. Cultural differences and divergent social norms and attitudes make it easy to label Turkey as nonEuropean, especially if European identity is based on racial, ethnic and cultural features. ${ }^{4}$ However, Turkey has always seen Europe as a looking glass through which it perceived its identity and has consistently sought recognition and acceptance of its Europeanness. ${ }^{5}$

Complicating Turkey's ambiguous relations with the EU is Europe's own identity crisis, which begs the question "what is Europe?" Is it "Atlantic Europe," based on a collective defense, or is there a "core Europe" with roots in ethnicity and culture? As long as the identities of Europe and Turkey go undefined, Turkey's hopes of accession are dim.

\section{Turkey and the European Union}

In 1959 Turkey applied for associate membership in the newly founded European Economic Community (EEC), and became an associate member with the Ankara Treaty, signed on September 12, 1963 in Brussels. On April 14, 1987 Turkey applied for full membership. Although the European Commission noted Turkey's eligibility, its Opinion of December 18, 1989 detailed serious economic and political difficulties that rendered Turkish accession unlikely, such as the expansion of political pluralism, the state of democracy, the persistence of disputes with 
a Member State (namely Greece), the lack of a viable solution to the Cyprus problem, relative economic backwardness, especially in macroeconomic terms, the Kurdish question, and problems related to human rights. The most the Commission would offer was the continuation of relations as foreseen by the Association Agreement (signed in 1963) and a customs union agreement, signed on March 6, 1995 and put into effect on January 1, 1996. The customs union was one of the Ankara Treaty's goals - the other was, of course, full membership - and it demonstrated that the Turkish economy is able to deal with competitive pressure and adopt the Community's standards. ${ }^{6}$

Turkey has been preparing for EU membership for almost 40 years, since signing the Ankara Treaty whose Article 28 looks toward eventual membership when the parties would feel ready to assume their mutual responsibilities. ' Continued delays are seen in Turkey as unfair and discriminatory, especially in light of Turkey's Cold War inclusion in the North Atlantic Treaty Organization (NATO). As Turkish president Süleyman Demirel remarked bitterly: "When the defense of European civilization [against communism] was at stake, they didn't say we were Turks and Muslims."

Since the end of the Cold War, Turkey has stood on the sidelines while the former Warsaw Pact countries have edged closer to membership in Europe's most élite club. In 1991, the newly democratic states of Central and Eastern Europe signed the Europe Agreements with a final objective of membership (all have since applied) and in 1993, the European Council's Copenhagen statement clarified the criteria for membership for them and for all other applicants. ${ }^{9}$ Turkey was once again overlooked when former Commission president Jacques Santer proposed Europe's Agenda 2000 on July 16, 1997, setting the Commission's strategy for EU enlargement, and suggested opening accession negotiations in 1998 with the Central and Eastern European countries, Cyprus, and Malta.

The European Council repeatedly confirmed Turkey's eligibility in its Luxembourg summit (1997), Cardiff summit (1998), and Cologne summit (1999), yet decided to adopt only a pre-accession strategy - prepared by the Commission on March 4,1998 - in June 1998. In response to the Luxembourg summit decisions, the Turkish government in December 1997 decided to suspend all political dialogue with the EU, thereby cutting the line of communication between Turkey and the EU on all political matters. A breakthrough came in December 1999, when the 
European Council decided in its Helsinki summit to grant Turkey a candidate status.

European objections to Turkish membership can be grouped under four main headings: (i) economic factors - Turkey would require substantial financial compensation from the EU in order to meet the level of Western European economies; ${ }^{10}$ (ii) the Kurdish problem - the recent crisis resulting from Abdullah Öcalan's capture ${ }^{11}$ demonstrated that the Kurdish problem has become a European problem; (iii) the Greek veto and the Cyprus problem; and (iv) the state of Turkish democracy and human rights - which are perceived to lag behind EU standards.

As per the Commission's Communication on a European Strategy for Turkey (the pre-accession strategy), progress reports for Turkey were published in November 1998 and October 1999 evaluating Turkey's candidacy according to the Copenhagen criteria. These reports stated that: "Recent developments confirm that, although the basic features of a democratic system exist in Turkey, it still does not meet the Copenhagen political criteria. There are serious shortcomings in terms of human rights and protection of minorities. Turkey has many of the characteristics of a market economy. It should be able to cope, albeit with difficulties, with competitive pressure and market forces within the Union."12 Thus, according to the Commission, Turkey's main problem lies in the political aspects of Copenhagen criteria.

The aforementioned factors all legitimately complicate Turkey's relations with the EU but one important implicit factor is missing from the EU's stated objections - perceptions of Turks as culturally different and, essentially, non-European.

Consider the EU's evaluation of political conditions in other applicant countries, such as Bulgaria, Romania, and Slovakia. These countries were found to satisfy the Copenhagen criteria, despite the facts that their democracies are no more stable than that of Turkey and that Turkey is ahead of these countries in its economic capacities and its ability to adopt the acquis communautaire - the body of Community law, regulations, and directives - as demonstrated by Turkey's performance under the customs union and by its economic performance in the last decade. Thus, there must be another variable, aside from politics and economics, that accounts for Turkey's perpetual outsider status. That variable is identity. The remarks of European Parliament President Nicole Fontaine regarding Turkey's membership illustrate the importance of this variable: "its - 
Turkey's - accession would of course be to the Union's advantage economically and politically, but it would not be possible to evade the problem of cultural integration. It will arise, and so will the issue of what criteria to adopt to determine the limits of Europe's new borders in the face of the new applications from countries to the east or south of the Union which would inevitably be encouraged by Turkey's accession. To tell the truth, Parliament is divided on this burning issue at present."13

In a survey conducted among the members of the European parliament, Turks were found to be the least desirable immigrants in the EU. ${ }^{14}$ Of course, the leaders of EU countries will not publicly admit that their reservations are related to Turkey's Europeanness or religion, but remarks such as that of the CDU representatives show that Turkey's identity is a serious concern. Former German chancellor Helmut Kohl announced firmly in 1997: "Turkish membership in the EU is not possible." I5 In addition, remarks by former Greek foreign minister Theodor Pangalos about Turks being allowed to "to drag their bloodstained boots across the carpet" in EU capitals and his labeling of Turks as "bandits, murderers, and rapists" 16 reinforced Turkish feelings of discrimination. Within this context, Turkey's future in the EU is problematic.

\section{What Is Europe?}

Questions about Turkey's identity are directly related to the concept of a European identity. In the post-Cold War period, European identity has become a focal point for analyzing European politics. ${ }^{17}$ European identity has been reconstructed with ethnocultural dimensions clarifying who is European and who is not. Europe's uncertain boundaries increase the importance of historical, racial, ethnic, and cultural factors in constructing a Self vs. Other identity.

One theory on European identity posits that: "The very idea of what Europe was from the beginning is defined partly in terms of what it was not. In other words, the Other, i.e. the non-European barbarian or savage, played a decisive role in the evolution of the European identity and in the maintenance of order among European states." 18 Thus, all that is nonEuropean determines what Europe is, and in the case of a non-European identity, it is all that is European that sets its self-image. The concepts of Europeanness and non-Europeanness are thought to be mutually exclusive 
with the line of demarcation between "civilized" Europe and "barbaric" non-Europe.

As Anthony Smith writes: "Identities are forged out of shared experiences, memories and myths, in relation to those of other collective identities. They are in fact often forged through opposition to the identities of significant others, as the history of paired conflict so often demonstrates." Who and what, then, are Europe's significant others? ${ }^{19}$

The Others of Europe have, of course, changed over time. But, what is important is that the politics of inclusion in and exclusion from the EU is the modern day reflection of the concept of paired conflict. As Stuart Hall suggests: "Throughout their careers, identities can function as points of identification and attachment only because their capacity to exclude, to leave out, to render 'outside,' abjected." ${ }^{20}$

In addition to attractive economic advantages, part of Turkey's desire to join the EU is grounded in its desire to have its Europeanness legitimated, as is the case for the Central and Eastern European countries. The identity of the "new Europe" is based on a common cultural heritage, with foundations in ancient Greece, Christianity, and Europe of the Enlightenment. ${ }^{21}$ If religion is an important variable in determining Europe's boundaries, then it is an obvious, if unspoken, influence on EU perceptions of predominantly Muslim Turkey. According to an article in the Washington Times: "Western fears of Islam are making it difficult for Muslims to be accepted in Europe. That fear is partly the result of a mediadriven Islamophobia that links Islam to terrorism and fundamentalism." ${ }^{22}$ It is within this context that the CDU's declaration about Turkey becomes important.

\section{A History of Turkish-European Relations}

The history of Turkish-European relations dates back to the Middle Ages when, according to Martin Wight: "Western Christendom expanded on the basis of a steady cultural, religious and linguistic penetration of surrounding lands and found itself in the east confronted by the "unreciprocating will of the unspeakable Turk." ${ }^{23}$ Thus, it is important to begin a discussion of Turkish-European history with the Turkish Republic's predecessor, the Ottoman empire.

Turks have been a part of Europe geographically since their arrival in Asia Minor in the eleventh century, economically since the sixteenth 
century as trade routes expanded, and diplomatically since the nineteenth century, when the Ottoman empire was officially included in the Concert of Europe. At the Paris conference of 1856, Europe's great powers agreed that the territorial integrity and the independence of the Ottoman empire were vital to Europe's stability. However, from the start, some Europeans had reservations that the Turk "possibly did not belong to the progressive races of mankind." ${ }^{24}$ According to M.E. Yapp: "It is no doubt true that during the period from the 13th to 16th centuries, the concepts of Christendom and Europe tended to coincide." ${ }^{25}$ Indeed, as French writer Ernest Renan wrote in the nineteenth century: "Europe was born as a result of the Greek miracle. It grew with the Greek-Latin culture, experienced a Renaissance and is Christian."26 Thus, Europe, as conceived by its noble élites, focused its hostility on Islam. Military resistance to the Ottoman empire was intensified by the role of religion. ${ }^{27}$

It is interesting to note that the term "Europe" was increasingly used in relation to the rise of the Ottomans and the threat they posed to Christianity. ${ }^{28}$ Europe as a term has been used from the thirteenth century onward; before that, there was no notion of Europe, but rather Christendom. 'Nothing, it was stated, better contributes to maintain the peace between the Christian princes (the "tranquility of Europe") than the fear which the Turkish forces can inspire in their neighbors." ${ }^{29}$ For example, George Podiebrand's plan in 1458 for a League of Perpetual Union of Christian Princes was designed for defending Europe against the infidel Turks by creating a common European army. Thus, "the dominant Other in the history of the European states system is 'the Turk.' In contrast to the communities of the 'New World,' the military might and physical proximity of the Ottoman empire, combined with the strength of its religious tradition, made it a particularly relevant Other in the evolution of European identity." ${ }^{30}$

For the Europeans, the threat from the East was substantial given that the Turks were at the gates of Vienna as late as 1683. The Turks represented all that was negated in the European identity; savage, barbarian, despotic, oppressive, violent, and a threat to European civilization. Montesquieu, for example, used the Ottoman empire as the differentiating element of the European identity; the differentiating factors were its despotism and Islamic values. ${ }^{31}$ One can find similar patterns in perceptions of the Turks throughout centuries as "the myth of the "vicious Turk' who appeared to embody the worst sort of nightmares for the champions of European civilisation [sic]." ${ }^{\prime 32}$ 
Thus, the perception of Turks as Other in Europe is deeply embedded in Europeans' collective memory. Since, as Kevin Robins writes, "the projections of the European psyche have been and remain, fundamental impediments to cultural encounter and understanding, ${ }^{, 33}$ the portrayal of Turks in the manner described above remains a serious obstacle to Turkey's inclusion in Europe. Turkey seems to be confronted with a cultural arrogance and cultural hatred from some quarters in Europe because as the Other, it is "marked by an insurmountable particularity, and consequently can never be assimilated into our culture. ${ }^{\prime 34}$

Turkish relations with Europe changed with the Ottoman decline and eventual demise. Beginning in the seventeenth century, the Ottomans gradually lost their military superiority and fell behind the European states in technological development. As a result, the Ottomans initiated a process of modernization in order to retain their power, looking west for a model. European-educated Turkish scholars and diplomats began to import European ideas, lifestyles, and ways of thinking into the empire. They also introduced such concepts as nationalism, patriotism, and liberty into Ottoman society. Thus, Europe became a mirror through which the Ottoman élite perceived its own weaknesses, differences, and traits. The Ottoman process of Europeanization became critical in defining what the Turkish people rejected, namely non-European elements of their national character. Because the Turkish élite transformed Ottoman society from above, a gap formed between the ruling élite and the masses in their perceptions of Europe and modernity. Turkish philosophers, the Young Turks, and the Young Ottomans movements were all inspired by Europe. ${ }^{35}$

When the Turkish Republic was created in 1923, the new Turkish élite aimed to eliminate almost all aspects of the old Ottoman system. Arbitrary rule was replaced by rule of law, and religion as the legitimizing factor of the system gave way to legitimacy derived from the personal charisma of Mustafa Kemal Atatürk and new institutions such as the Turkish parliament. Turkish policymakers were adamant in their desire for Europe to accept the new Turkish state's Europeanness. This objective is clearly evidenced by changes the Turkish government made during the first three decades of the Republic's existence: the abolition of the Sultanate in 1923 and the Caliphate in 1924, the change from the Arabic alphabet to the Latin alphabet, changes in the dress code, and an acceptance of Western standards in education, health, and public life. These were all efforts aimed at creating a modern, secular, European nation-state, and at 
elevating the Turkish state to the level of contemporary civilizations read, Europe.

The new state also eliminated the influence of Islam from the political discourse in a bid to rid itself of its Middle Eastern character and move toward Europe. As Çağlar Keyder writes: "For the Turkish intelligentsia, nationalism and secularism constituted tickets to modernization and Westernization." ${ }^{36}$

Turkey's incorporation into Western European security arrangements after World War II seemed to afford Turkey the European legitimacy it always sought. During the Cold War, Europe's identity was reinvented along security lines and the Communist bloc became the Other/nonEurope. As long as the line of demarcation was the Iron Curtain, realpolitik dictated that Turkey's Europeanness not be openly questioned.

The need for Turkey as a buffer against Soviet expansion also helped Turkey gain associate membership in the EC in 1963. For the EC, the applications of Turkey and Greece ${ }^{37}$ in 1960s bolstered the newly founded organization's international leverage. But, the disappearance of the Soviet enemy eroded Turkey's position in the Europe. It no longer served a clear function, and thus was shunted to the back of the line of candidates for EU membership in the 1990s.

Turkey today stands at a crossroads: it is not included in the EU's next enlargement phase and there is great uncertainty as to whether it ever will be included. According to Turkish Prime Minister Bülent Ecevit, the reason behind Turkey's exclusion is religion. Turkey still faces the prejudice of those who believed in the Little Europe model of Jacques Delors and Helmut Kohl: that the EU should not expand beyond Christendom.

\section{Challenges after the Cold War}

The end of the Cold War seems to have sent Turkey's relations with Europe back in time to nineteenth century ethno-nationalism. The replacement of the ideological East-West conflict with ethnic, religious, and historical conflicts emphasized Turkey's non-Christian, and hence non-European, character. ${ }^{38}$ The search for Europe's new Other has focused on the south of Europe, in Islam, and in the foreigners living in Europe outsiders in race, religion, ethnicity, and culture. Racism is becoming a 
major component in European politics, as evidenced by the 1999 electoral gains of racist right-wing parties in Austria and Switzerland.

In 1997, the European Commission ordered an opinion survey asking citizens of the 15 member states whether they considered themselves racist; many of the respondents did. ${ }^{39}$ Europeans share a growing concern about the Other - the non-European, non-white, possible migrant. ${ }^{40}$ There is no EU policy regarding discrimination against immigrants. The 1992 Treaty of European Union and the 1997 Treaty of Amsterdam both deal with immigration and citizenship as matters of common interest but leave the administration of such matters to national authorities. Thus, racism at the national level is reflected in the EU to a certain degree. As Gerard Delanty argues, by speaking of national identity and cultural boundaries, "the new European identity can disguise itself as an anti-racism. It is a diffuse racism that can speak in the name of both a national identity and Europeanism." 41

Turks constitute a substantial portion of foreign migrants in Western European countries. There are some two million Turks living in Germany alone. Their presence has stirred hostile feelings among many Europeans. For example, a famous slogan of the extreme right in Germany is "Turks Out." Increasingly frequent attacks on migrant communities such as the Solingen incident, in which a number of Turkish migrants were burned to death, is another barometer of European's hostility toward Others. As journalists Stephen Bates and Martin Walker note: "Consult any of the taxi drivers of many of Europe's cities (those who are not themselves Turkish that is) and you will be regaled with hostility to immigrants, all lumped together as Turks or, more insulting still, "shish kebabs." "'+2

Interestingly, these anti-Turkish sentiments are not only found among Europe's working classes, but also among EU policymakers, as measured by a survey of members of the European parliament. ${ }^{43}$ In addition, EU politicians such as CDU parliamentary party leader Wolfgang Schauble, publicly announce that Turkish membership in the EU might be "too much for Europe" and that Turkey's membership could endanger the identity and political workability of the EU. ${ }^{44}$

The Turkish government perceives these developments as indicators that ethnonationalism and religion are the real reasons behind Turkey's exclusion from the EU. According to a press release from Turkey's ministry of foreign affairs: "The danger, it seems, is to create new lines of division, new discrimination, new compartments; defined, explicitly or 
implicitly on criteria of ethnicity, religion, region, levels of development, and civilization. The danger, if it grows freely, will somewhat confirm the prophecy of those who proclaim 'the clash of civilizations' as the inevitable, imminent fact of the next decades." 45

Parallel to Europe's identity reformulation, Turkey is going through its own identity crisis, one that began in the nineteenth century and still lingers. Turkey is split into two camps: one is based on the modern, secular, Western-oriented discourse, and the other is traditional, Islamist, and Oriental in its formulations. ${ }^{46}$ The new Turkish Republic succeeded in repressing the conservative, reactionary tendencies for some time. However, the undercurrent of traditionalism was always there and it found fertile ground in the post-Cold War era. In the past decade, a number of traditional elements, most prominently the Islamists, began to challenge Turkey's official identity. The Islamic movement in Turkey has always opposed the process of modernization and Europeanization. During the Ottoman period, "Din elden gidiyor" ("we are losing our religion") was a favorite protest by religious conservatives expressing their discontent and opposition to modernization efforts.

The best illustration of the clash between these two camps is the 1993 Sivas incident, where a group of intellectuals, artists, and writers gathered in the town of Sivas to celebrate the 600th anniversary of Turkish poet Pir Sultan Abdal. Violent Islamic protestors laid siege to group's hotel and set it afire, killing 37 people.

During the Cold War, Turkey's inclusion into European security arrangements was perceived to have settled the identity dispute in favor of the modernizers. The Cold War helped suppress religious reactionaries and their opposition to Turkey's European bent. However, the EU's consistent refusal to admit Turkey after the Cold War has played well into the hands of religious conservatives. As Çağlar Keyder notes:

The European policy of ambivalent inclusion exacerbates the Turkish identity problem...Thus, the behavior of the EC paradoxically undermines the credibility of the pro-western political forces within Turkey, who have to engage in much defensive posturing ... Each delay by the EC Commission and each veto by Greece recalls the search for identity that characterized the decline of the Empire - that unsettled issue, which has dominated Turkish cultural life ever since. ${ }^{4}$ 
Islamist groups in Turkey, such as the outlawed Welfare Party and its successor, the Virtue Party, effectively utilize anti-European tendencies in the Turkish population for their own political ends. The Welfare and Virtue parties' chants are reactions to European objections to the "uncivilized" Turks. They claim that the origin of European civilization is in Islam. For example, Necmettin Erbakan, Turkey's former Islamist prime minister and leader of the Welfare Party, capitalized on the argument that "Europe is an expression of imperialism and we need to turn to our true friends; the Islamic brothers in the Middle East." ${ }^{18}$ Despite their decline in electoral popularity over the past four years, the Islamists mobilize their supporters around opposition to European culture and the process of westernization. Erbakan was forced from power in 1997 by the military because of his inability to enact educational reform that would close Islamic schools - the İmam-Hatip lycees - illustrating the clash between secular forces and religious reactionaries.

Turkey's ongoing identity crisis has contributed to its marginalization within Europe. The presence of Turkish migrant workers in Germany, for example, has led many Europeans to believe that Turks really are Europe's Others. The long history of Turkey's association with Europe as an EC associate member and a loyal NATO ally did not decrease the differences between Turkey and Europe; it made them more visible.

\section{What the Future Holds}

Throughout contemporary history, Turkey's relations with Europe have served as an indicator for measuring the success of Turkey's modernization efforts, as well as the acceptance of Turkey's European credentials. When, for example, the customs union agreement was signed in 1995, initial reports in the Turkish media announced that Turkey had taken one step toward Europe and one step away from the Middle East and the dangers of Islamic fundamentalism.

Unfortunately, the redefinition of Europe's identity along ethnonational and cultural lines - emphasizing a shared culture, civilization, and heritage - may mean that Turkey will not qualify for EU membership and, therefore, will not be part of "European civilization." It seems that Turkey's long history of association with the rest of Europe has finally reached a turning point.

The fact that Turkey has fallen behind countries like Bulgaria, Cyprus, 
and Poland in the race for EU membership has deepened the divide in Turkey among Western-oriented modernizers and Islamic-oriented conservatives. As for Europe, the recent emphasis on ethnicity and culture poses a serious obstacle for a dynamic transformation into a United States of Europe.

The October 1999 progress report issued by the European Commission may signal a desire on the EU's part to patch up relations with Turkey. The favorable report recommended elevating Turkey from being an applicant to a candidate country. Of course, the Commission recommended beginning accession negotiations with the second wave countries but not yet with Turkey. The European Council's Helsinki summit of December 1999 acted on the Commission's suggestion and elevated Turkey to a candidate country, albeit with a number of conditions. It is still too early to predict the outcome of the Council's decisions, though, and Turkey's position in Europe is still undecided.

\section{NOTES}

1. Chris Nuttall and Ian Traynor, "Kohl tries to cool row with Ankara", Guardian, March 7, 1997.

2. Council of the European Union, Presidency Conclusions, Dec. 11, 1997.

3. For further information, see the Commission's Composite Paper of 1998 and 1999 as well the Progress Reports for Turkey 1998 and 1999.

4. For further information, see Pieterse Nederveen, "Fictions of Europe", Race and Class, Vol.32, No.3 (Jan. 1991), pp.3-10; Marco Martiniello (ed.), Migration, Citizenship, and Ethno-National Identities in the European Union (Aldershot: Avebury, 1995); Brubaker, William, Rogers. Citizenship and Nationhood in France and Germany (Cambridge, MA: Harvard University Press, 1992).

5. Meltem Müftüler-Bac, Turkey's Relations with a Changing Europe (Manchester: Manchester University Press, 1997).

6. The European Commission, Regular Report for Turkey, Oct. 1999.

7. Ibid., p.l.

8. Stephen Bates and Martin Walker, "Analysis: Turkey: Bridge over BATES troubled waters. The Bosphorus crossing links Europe and Asia, yet despite their geopolitical importance and long membership of NATO, the Turks batter in vain on Europe's door." Guardian, Dec. 2, 1998.

9. During the 1993 Copenhagen summit of the European Council, the EU set the criteria for membership as (i)stable institutions, democracy, respect for human rights, and rule of law (ii) a functioning market economy and a capacity to cope with competitive pressure, and (iii) an ability to take on the obligations of membership such as adherence to aims and policies of the Union.

10. The Turkish economy is, however, very competitive compared to the rest of the applicant countries as both the Commission's Composite Paper of 1999 and Progress Report for Turkey of 1999 demonstrate.

11. Abdullah Öcalan, the leader of the separatist terrorist organization, PKK (Kurdish Workers' Party) fled from Syria to Italy in November 1998 where he was captured by the Italian 
authorities. A crisis between Turkey and Italy erupted over Öcalan and he fled to Kenya where he was captured in February. In May 1999 his trial began in the State Security Court and he was sentenced to death penalty in June 1999 on accounts of separatism, treason, and manslaughter. Throughout his trial, various demonstrations took place in European capitals for and against Öcalan and Kurdish separatism.

12. 1999 Regular Progress Report, Turkey, Oct. 14, 1999.

13. Speech given by Nicole Fontaine, President of the European Parliament, at the Helsinki European Council, Dec. 10, 1999.

14. Gallya Lahav, "Ideological and Party Constraints on Immigration Attitudes in Europe," Journal of Common Market Studies, Vol.35, No.3 (March 1997), p.388.

15. Minutes of European People's Party meeting, Val Duchesse, Brussels, March 4, 1997.

16. Observer Column, Financial Times, Feb, 19, 1999.

17. For further information see Brigid Laffan, "The politics of identity and political order in Europe," Journal of Common Market Studies, Vol.34, No.1 (1966), pp.81-102; Michael Smith, "The European Union and a Changing Europe: Establishing the Boundaries of the Other," Journal of Common Market Studies, Vol.34, No.1 (1996); Meehan, Elizabeth. Citizenship and the European Community (London: Sage, 1993); Garcia, Soledad. European Identity and the Search for Legitimacy (London: Pinter, 1993.)

18. Iver Neumann and Jennifer Welsh, "The Other in European self-definition: an addendum to the literature on international society," Review of International Studies, Vol.17 (1991), p.329.

19. Anthony Smith, "National Identity and the Idea of European Unity," International Affairs, Vol.68, No.1 (1992), p.75.

20. Stuart Hall, "Introduction: Who needs Identity?" in Stuart Hall and Paul du Gay (eds.), Questions of Cultural ldentity (London: Sage, 1996), p.5.

21. See Elizabeth Prodromou, "Paradigms, Power, and Identity: Rediscovering Orthodoxy and Regionalizing Europe," European Journal of Political Research, Vol.30, No.2 (1996), pp. 125-54, and Iver Neumann, "European Identity, EU Expansion and Integration/Exclusion Nexus," Alternatives, Vol.23, No.3 (1998), pp.397-416.

22. Jason Keyser, "Denmark struggles to handle immigration flux Social programs, cultural identity feel rising strain," Washington Times, May 301999.

23. Martin Wight, System of States (Leicester: Leicester University Press, 1977), p.120 as quoted by Paul Rich, "European Identity and the myth of Islam: A Reassessment," Review of International Studies, Vol. 25 (1999), p.438.

24. Neumann and Welsh (1991), p.344.

25. M.E. Yapp, "Europe in the Turkish Mirror," Past and Present, No.137 (1992), pp.138, 155.

26. See English conferences of Renan, Ernest. Rome and Christianity and Marcus Aurelius. Translated by Clara Erskine Clement (Boston: J.R. Osgood and Company, 1880).

27. For further information, see Lord Kinross, The Ottoman Centuries (New York: William Morrow and Co. Inc, 1977).

28. For further information, see Delanty, Gerard. Inventing Europe: Idea, Identity and Reality (London: Macmillan Press, 1995); Neumann and Welsh (1991); Yapp (1992); and Hay, Denys. Europe: The Emergence of an Idea (Edinburgh: Edinburgh University Press, 1957).

29. Yapp (1992), p. 144.

30. Neumann and Welsh (1991), p.330.

31. Jack Lively, "The Europe of Enlightenment," History of European Ideas, Vol.1, No.2 (1981), p.91.

32. Rich (1999), p.445.

33. Kevin Robins. "Interrupting Identities:Turkey/Europe," in Hall and Gay, eds (1996), p.64.

34. Ibid, p.66.

35. Niyazi Berkes, Türkive'de Çağdașlașma- The Process of Civilization in Turkev (Ankara: Bilgi Yayınevi, 1973).

36. Cağlar Keyder, "The Dilemma of Cultural Identity on the Margin of Europe," Review, Vol.16, No.1 (1993), p. 23. 
37. Greece and Turkey applied to the EEC in 1959 only two years after the Rome Treaty was signed.

38. Ola Tunander, "A New Ottoman Empire? The Choice for Turkey: Euro-Asian Centre vs National Fortress," Security Dialogue, Vol.26, No.4 (1995), p.416.

39. Roger Boyes, "Year of good intentions leaves racist monster lurking in the cellar," The Times, Dec. 27, 1997.

40. Garcia (1993), p.14.

41. Delanty (1995), p. 154

42. Bates and Walker (1998).

43. Lahav (1997).

44. Minutes of European People's Party meeting, Val Duchesse, Brussels, March 4, 1997.

45. Turkish ministry of foreign affairs press releases, Dec. 1997; Statement by Turkish Minister of Foreign Affairs İsmail Cem.

46. For further information, see Metin Heper, "Islam and Democracy in Turkey: Toward a Reconciliation," Middle East Journal, Vol.51, No.1 (1997) pp.32-45 and Meltem MüftülerBac, "The Never-Ending Story: Turkey and the European Union," Middle Eastern Studies, Vol.34, No.4 (1998), pp.240-58.

47. Keyder (1993), p.32.

48. This was a common statement made by Erbakan on various occasions, he emphasized this idea when he became the prime minister in summer 1996 and made his first official trips to such countries as Libya, Malaysia, Indonesia, and Iran in August 1996. 
Copyright $@ 2002$ EBSCO Publishing 